\title{
АРХЕОАОГИЯ. ЭТНОАОГИЯ
}

УДК 902/904,902.6

DOI: $10.15350 / 26191490.2020 .2 .6$

A. А. Красноперов

\section{ДАТИРОВКИ КОМПАЕКСОВ С БУСАМИ Т-М-362 НА РИМСКОМ ПОГРАНИЧЬЕ В СВЯЗИ С НАХОДКАМИ В ПРИКАМЬЕ}

Решение вопроса хронологии прикамских древностей может опираться на датировки неместных предметов с известной хронологической позицией: фибулы, пряжки, бусы и т. п. Статья является частью цикла, посвященного одной группе бус - «с ресничковым орнаментом» - Т-M-362/A-480-482,490,496. Бусы этой группы найдены в 38 погребениях 8 мазунинских, 10 погребениях 4 азелинских могильников. Для корректного переноса датировок и понимания хронологических возможностей находок, в данном случае находок бус группы T-М-362 в Прикамье, необходимо рассмотреть датировки комплексов в других регионах их бытования. В этой публикации внимание сосредоточено на комплексах в римском пограничье: в сарматской и черняховской среде. Как показал обзор, «розетковые» бусы характерны для сарматских групп на лимесе, но дальше количество находок резко падает. По сопутствующим находкам погребения с территории современных Сербии, Венгрии, Румынии датируются второй половиной II в. - первой половиной III в. н.э., с единичными запаздываниями. Это соответствует датировкам, предлагавшимся для категории находок в целом.

Ключевые слова: могильники, хронология, бусы, сарматская культура, черняховская культура, Прикамье.

Решение вопроса датировки по аналогиям по привычке осуществляется прямым переносом без каких-либо обоснований. Очевидно, что такой метод неприемлем, но продолжает использоваться, поскольку это «легко и просто» [Комар, 2010, с. 194, прим. 5]. Во многих ситуациях нужно проверять, на каких реальных фактах основаны датировки. И перепроверка иногда разрушает казавшиеся незыблемыми системы (см. пример с Суук-Су, описанный А. К. Амброзом [Амброз, 1989, с. 7, 9, 11]. В других, более редких случаях проверка подтверждает хронологическую систему и дополняет ее.

Для корректного переноса датировок и понимания хронологических возможностей находок, в данном случае находок бус группы Т-M-362 в Прикамье [Красноперов, в печати], необходимо рассмотреть датировки комплексов в других регионах их бытования.

В отношении рассматриваемой группы бус можно выделить несколько ареалов распространения: сарматские группы на римском пограничье (и в Крыму), германоязычные (со смешанным населением) культуры (пшеворская, вельбаркская, черняховская и др.) и районы под их влиянием (Кавказ, Прибалтика), круг лесных культур Восточной Европы (рязано-окских могильников, «древнемордовская», азелинская, мазунинская).

Среди бус Барбарикума М. Темпельманн-Мончинска выделила группу XXIII, тип 362, с основой различного цвета и розетковым орнаментом, как наиболее распространенные среди мозаичных в фазах C1b-C2 (220/230-300/320 гг.) центрально-европейской хронологии [Tempelmann-Maczinska, 1985, tab. 8, s. 95]. Хотя появляются несколько раньше, на фазе В2/C1 (160/180-200 гг.), а пережиточно встречаются и позднее [Tempelmann-Maczinska, 1985, s. 60]. К тому же времени относят находки в Польше [Kokowski, 1993, цит. по: Румянцева, 2008, с. 98; Stawiarska, 1987, s. 73-74, kat. 127]. В Скандинавии отнесены к фазам C1-C3 (150/160-400 гг.) по хронологии У. Лунд-Хансен, с пиком распространенности в фазах С1-C2 
(150/160-310/320 гг.) [Румянцева, 2019, с. 10]). О. А. Хомякова распространение бус с декором (ресничковый, меандровый и шахматный; признак 63), в том числе с розетковым орнаментом, относит к фазе II самбийско-натангийской культуры (B2/C1-C1a) [Хомякова, 2012, с. 259, рис. 9-63].

Производство было налажено в римских провинциях и первыми потребителями становились ближайшие соседи. С хронологии этих памятников и стоит начать.

\section{Изученность вопроса}

Находки в римском пограничье представлены в небольшом очерке, у которого ожидается дополненная версия [Grumeza, Bârcă, 2020], Л. Грумезы. Существенно, что она собрала комплексы и переопубликовала их в едином томе, что намного облегчает работу. Интересующий тип входит в моду со II в. и пользуется спросом весь III в., единичные случаи известны в конце IV в. (Тиседоб-Сигет, п. 19) [Grumeza, 2014, p. 100, pl. 33-1; 2018, p. 206]. Бусы крымских памятников включены в свод Е. М. Алексеевой [1982], но, главное, монографически изучены в диссертации А. А. Стояновой [2006]. Типы Алексеева-480,481,496 датированы II-III вв. [Алексеева, 1982, рис. 22]. Несколько непонятно соотнесение с этой группой типов Алексеева-487-489 [Алексеева, 1982, с. 43, табл. 49-8-11], где, судя по рисункам в ракурсе, реснички несколько иные. В крымских памятниках А. А. Стоянова выделила их в тип X.I.1, зеленые с тремя глазками, сердцевина красная, реснички желтые и зеленые, в трех комплексах, которые отнесла к концу II - первой половине III в. [Стоянова, 2004, с. 285]. Бусы черняховских могильников обобщены в диссертации О. В. Гопкало [Бобровська, 2000]. В черняховском ареале Она отметила 5 цветовых вариантов типа Пс XIII/5 в могильниках, территориально приближенных к Империи. Бусы характерны для раннего этапа черняховской культуры, хронологической группы 1a, включающей римские импортные изделия, аналогии которым происходят из памятников, прекративших существование в период «скифских войн», но никогда не встречавшихся с вещами последней трети III в. [Гопкало, 2008, с. 58-59, 103, 96, 107, рис. 3.5, табл. VI].

Комплексы с бусами с ресничковым орнаментом $^{1}$

На данный момент нет единого мнения о местах производства бусин T-M-362. Ближайшей of-

\footnotetext{
${ }^{1}$ Цель собрать обязательно все комплексы не ставится.
}

ficinae являются мастерские Тибискума, основным рынком сбыта которых были сарматские группы в Воеводине (северная Сербия): Vršac-Dvorište Eparhije Banata (пп. 6, 9-11, 14) [Grumeza, 2014, pl. 94-96, 97-1-18], Kovačica-Stare jame (п.3) [Grumeza, 2014, pl. 62-3.4], Pančevo-Vojlovica (пп. 23, 24, 32, 49) [Grumeza, 2014, pl. 72-9-13, 73, 74-8-22, 78-10-15], Ruski Krstur, Vršac-Ulica Podvršanska, Crvena Crkva (данные по: [Benea, 2004², s. 242-243]; цит. по: [Grumeza, 2018, s. 200]). Но многие из них опубликованы только в выставочных каталогах.

На территории Венгрии бусы рассматриваемой группы найдены в сарматских могильниках Madaras-Halmok, пп. 114, 152 [Köhegyi, Vörös, 2011, tabla 26, 33-10-13, sz. tabla 1], Tiszadob-Sziget, п. 19 [Istvanovits, 1993, s. 100, 103, Abb. 10-5.], Kiskundorozsma-Subasa, 26/78, п. 121 [Bozsik, 2003, kep. 4-9, 11-13], Mako-Pap-hat 1, пп. 2, 14 [Gyöngyi, 2012, p. 253-254, 258, abra 3-5, 13-15], Abony-39, пп. 71, 95 [(Gyöngyi, 2011, s. 133-134, 136, tabla 29-30, 33-34], Cegled 4/3, п. 607 [Gyöngyi, 2011, s. 169-170, tabla 63-64], Szeged-Algyon, п. 70 [Köhegyi, Vörös, 1989-1990, s. 71, tabla II-7], Tiszafoldvar-Teglagyar, п. 66 [Grumeza, 2018, pl. VI-4]. Восточнее они встречены в трех из 18 могил сарматского кладбища Foeni-Cimitirul Ortodox (Румыния) (пп. 8, 14, 15) [Grumeza, 2014, pl. 19-1-12, 20-7-11; 2018, pl. VII], датирующегося в целом концом II - третьей четвертью III вв. н. э.

Находки Алексеева-б/т, 481, 490 происходят из бесполезных раскопок Ю. Кулаковского в Пантикапее и беспаспортной из Херсонеса. Тип Алексеева-480 найден в Совхоз-10, п. 164, Алексеева-496 - в Совхоз-10, пп. 146, 148а. В последних двух погребениях таких бус нет. Но есть в Совхоз-10, п. 147=к.я.XV/y.1 [Стржелецкий и др., 2003-2004, табл. 59-21; Высотская, Рыжова, 1996, с. 124, рис. 3-40, 41]. Находка Алексеева-482 происходит из Тиритака, п. 8=ск.V/1934 (Кобылина, 1941, с. 81-82, рис. 116-120). По данным А. А. Стояновой бусы типа X.I.1 найдены в Нейзац, п. 25 (глухое стекло), Мичурино (прозрачное стекло), Неаполь Скифский, ск. 155 [Пуздровский, 2003 , с. 132 , рис. 5-6]. В последнем случае бусина относится к другому типу - Алексеева-404-406.

В черняховской культуре, тип Гопкало-Пс XIII/5, найдены в Петрикивцы, пп. 34, 38 (не опубликован), Романово Село, п. 7 (недоступен), Ружичанка, п. 25, Чернелив Русский, пп. 54, 99, 135, к.с.

\footnotetext{
2 Это издание осталось недоступным.
} 
При полной публикации памятника [Герета, 2013, c. 55] бусина в последнем погребении не отмечена.

Датировка комплексов бус с ресничковым орнаментом

Могильники сарматского населения на лимесе дают достаточно стандартное сочетание находок: бусы с шахматным и 8-видным орнаментом, фибулы с эмалью разных форм, фибулы группы Альмгрен-VI, небольшие колокольчики, подвески-коробочки (Kiskundorozsma-Subasai, п. 121, Вршац, пп. 6, 9-11, Панчево, п. 24). Подвески в виде однолезвийных топориков (Панчево, п. 23 (Рис. 7- $\Gamma^{1}$ ), Tisaföldvar-Teglagyar, п. 66) характерны для территории Центральной Европы, но встречаются вплоть до Крыма [Стоянова, 2005, с. 50-52]. Самые ранние из них датируются концом I в. до н. э. I в. н. э. и распространены в двух основных ареалах: в Польше и Германии (период С2 центральноевропейской хронологии), в вельбарской среде [Белевец, 2016, с. 59, 65] и у сарматского населения Подунавья, где распространяются в I-II вв.

Э. Риха относит фибулы ${ }^{2}$ типа Вадай-III/3/1/1 (Mako, п. 14 (Рис. 2-A), Abony-39, п. 71 (Рис. 2-Б) ко второй половине II - III в., А. Бёме - к II - началу III в. [Vaday, 2003, s. 338; Grumeza, 2014, s. 68]. Пельтавидные фибулы Вадай-III/4/1/4 (Foeni, п. 8 (Рис. 3-Б), Вршац, п. 14 (Рис. 4-Б) появляются в I в. н. э. (экземпляры без эмали), но распространены в середине II - первой трети III в. [Vaday, 2003, s. 343, cat. 124/2; Grumeza, 2014, s. 69]. Фибула Вадай-III/3/1/3 (Вршац, п. 6 (Рис. 4-B), Abony-39, п. 95 (Рис. 5-Б) самостоятельной датировки не имеет [Vaday, 2003, s. 343, cat. 124/1; Grumeza, 2014, s. 67-68]. «Сарматская» фибула (Abony-39, п. 71 (Рис. 2-Б) относится ко второй половине II первой трети III в. [Grumeza, 2014, s. 66]. Фибулы-коробочки (Вршац, п. 9) датируются в тех же интервалах [Grumeza, 2014, s. 70-72]. Судя по наличию декора на спинке треугольного сечения, фибулы из Mako, п. 2 (Рис.5-A) и Abony-39, п. 71 (Рис. 2-Б), и, может быть, Cegled 4/3, п. 607, должны соответствовать типу Яртыпоры по Й. Анджейовски с достаточно широкой датировкой, в зависимости от ареала распространения, В2-C1a - C1b-C2 [Andrzejowski, 2018], фибула со спинкой круглого сечения (Kiskundorozsma-Subasai, п. 121 (Рис. 1-Б), Амброз-16/II, того же времени.

${ }^{1}$ Изначально все иллюстрации скомпонованы в формате $2: 1$.

${ }^{2}$ Вся эта категория находок, а также детали поясов, еще потребуют уточнений.
Железный коррозированный наконечник пояса из Abony-39, п. 71 (Рис. 2-Б) относится к типу Мадыда-6, в целом датированному от В2 до С2 [Madyda-Legutko, 2011, s. 55-64, 212]. Полукруглые пряжки (там же (Рис. 2-Б) появляются во II в. и продолжают встречаться в начале III в. [Grumeza, 2014, s. 91].

Самым поздним комплексом оказывается Тисадоб-Сигед, п. 19 (Рис. 3-В), где найдена овально-рамчатая пряжка с заходящим до середины сечения рамки язычком, с высоким уступом и сегментовидным щитком с тремя заклепками конца IV в.

Крымские могильники сарматского времени более разнородны.

Склеп Тиритака, п. 8=cк.V/1934, с несколькими погребенными, ограблен. Из инвентаря сохранились глиняные и стеклянные сосуды середины II - середины III в. н. э. [Сорокина, 1977, с. 129, рис. 3-1; Алексеева, Сорокина, 2007, Стк. Ф10, с. 52, табл. 36-2,3], бронзовые украшения и лучковые фибулы 3 варианта. Находки в целом относятся ко ІІ-ІІІ вв. н. э.

В Совхоз-10, п. 142/к.я.XV/y.1 (рис. 7-Б) найдены стеклянный сосуд III-IV в., серьга того же времени и бронзовая позолоченная бляшка с сердоликовой вставкой, относящаяся к стилю Закшув-Кишпек (общая датировка вторая половина III - первая половина IV в.) [Красноперов, 2019, c. 107 , прим. 21 - там обзор]. По особенностям декора бляшки, могила относится ко второй трети IV в.

Кувшин из Совхоз-10, п. 164 (Рис. 7-А) может быть, по-видимому, соотнесен с типом Труфанов-7/1: узкогорлый, с петлевидной рукой, грушевидным туловом, на кольцевом поддоне, с плавным переходом горла в тулово. Сравнительно узко датированные комплексы относятся к ІІІ в. н. э., преимущественно первой половине [Труфанов, 2005-2009, с. 177, рис. 34, 35-1]. Ажурная фибула (более точный рисунок: [Костромичов, 2018, рис. 1-13]) принадлежит к типам римского военного снаряжения и датируется второй половиной II - первой половиной ІІІ в. [Костромичов, 2018, с. 110-111].

Могила Нейзац, п. 25 [Храпунов, 2006, с. 167-170, рис. 4, 36-37] (Рис. 8-А) неоднократно привлекала внимание своеобразием своего инвентаря. Обоймы головного убора с пунсонным орнаментом обнаружены в нескольких могильниках Крыма (Левадки, Нейзац, Чатыр-Даг, Битак, Неаполь Скифский, Опушки, Перевальное $\left.{ }^{3}\right)$

3 Эти находки были обобщены А. А. Стояновой в докладе на конференции «Лесная и лесостепная 
III в н. э. [Храпунов, 2011, с. 37; Стоянова, 2011, с. 124] и Прикамья. Меловые скульптурки известны в могильниках среднесарматского времени, но редки, для Крыма находка вообще уникальна [Храпунов, 2011, с. 46]. Фибула принадлежит к инкерманской серии лучковых подвязных, широко распространенных в первой половине III в. [Храпунов, 2006, с. 170]. Бронзовые зеркала с боковым ушком и орнаментом на обороте группы Хазанов-IX обычны в могилах II-III в. [Труфанов, 2005-2009, с. 265], но в середине III в. начинают замещаться зеркалами с петелькой на обороте.

Погребение в Мичурино (Рис. 6), совершенное в Т-образной катакомбе, было доследовано в ходе строительных работ в 1989 г. [Мульд, 2001]. Узкогорлая светлоглиняная амфора типа Шелов-D датируется концом II - первой половиной III в. [Шелов, 1978, с. 18-19; Внуков, 2006, с. 167; Диденко, 2014, с. 35-38; Иванова, 2011, с. 293-296; 2013 , с. 124-129], в том числе в комплексах с монетами Гордиана II (238-244), Галлиена (253-268), Юлии Домны (Бельбек II, Бельбек IV, Дружное, Нейзац, Скалистое III, Танковое). Лучковые подвязные фибулы 5 варианта появляются в конце II в., распространение получают в первой половине III в. [Кропотов, 2010, с. 80, 118-№ 249]. Серебряная пряжка с рамкой овальной формы, со слегка утолщенной передней частью, язычок прогнутый, доходящий до переднего края рамки, но без ступеньки у основания, щиток прямоугольный, фасетированный, типа Малашев-П6 гр. 2а [Малашев, 2000 , с. 199, 208] - в конце II в. - первой половине III н.э. Ременные наконечники с длинными фасетками, типа Храпунов-II/3 [Храпунов, 2008, с. 66], пластинчатые подвески на зажимах, бронзовое кольцо и обоймы нагайки являются характерной деталью «всаднических комплексов» конца II первой половины III в. [Безуглов, 2017, с. 105].

В черняховских памятниках бусы с розетковым орнаментом редки.

В Чернелив Русский, п. 99 найдены только бусы [Герета, 2013, с. 45]. Среди инвентаря Чернелив Русский, п. 54 [Герета, 2013, с. 37] (Рис. 7-Д) встречены широко распространенные в римское время ведерковидные подвески. Маленькие экземпляры из различных материалов датируются ранним временем, концом II в. - первой половиной III в., но встречаются и в IV в. [Гопкало, 2008, с. 64; полоса Восточной Европы в римское время», Куликово Поле, ноябрь 2019. Прикамские находки заслуживают отдельной публикации.
Стоянова, 2016, с. 130-132; Иштванович, Кульчар, 2017, с. 55-56]. Бытование прогнутых подвязных круглопроволочных фибул варианта Амброз-16/II-1-1 или Гороховский-А1 относится к 1-й, ружичанской, фазе черняховской культуры по Е. Л. Гороховскому [Гороховский, 1988, c. 42-43, рис. 1-9] или 1-му периоду по О. А. ГейИ. А. Бажану [Гей, Бажан, 1997, табл. 66-18], второй-третьей четверти III в.

Заслуга определения римской бронзовой чернильницы из Ружичанка, п. 25 (Рис. 7-В) принадлежит М. Б. Щукину. По хронологии этой категории находок А. Коковского, экземпляр относится к III группе, первой половине III в. (C1b/C2) [Гопкало, 2008, с. 107; 2012, с. 331]. На основе сериации оба погребения попали в хронологическую группу Гопкало-1А, первой половины - второй трети III в. [Гопкало, 2008, с. 97, 107].

Практически все рассмотренные комплексы укладываются в даты второй половины II - первой половины ІІІ вв. н. э., с единичными запаздываниями.

Перепроверка оснований датировок (некоторые еще придется уточнять) в памятниках близ границ Империи подтверждает общие даты, предложенные для этой группы бус. Но необходимо особо отметить одну очень существенную особенность их распространения. Для сарматов за Доном А. С. Скрипкин отметил лишь 2 находки (памятники не указаны ${ }^{1}$ ): типа Алексеева-489 и белая, с тремя глазками: зрачок красный, реснички «серые» и белые [Скрипкин, 1990, с. 83, рис. 28-22,17]. В публикациях О. Н. Мошеевой, защитившей диссертацию по сарматским бусам, этот орнамент специально не рассматривался. T. е. они есть у сарматского населения непосредственно вблизи границы, в меньшем количестве в крымских памятниках сарматского времени и полностью отсутствуют дальше. Традиционный канал поступления бус в Прикамье - через сарматские земли, что подтверждается картографией находок и совпадением типологического состава. Но не в этом случае. Огромное пространство без находок совершенно очевидно показывает, что поступление этой группы к прикамскому населению шло другим путем. Каким, еще предстоит установить, рассмотрев другие ареалы бытования бусин с розетковым орнаментом.

${ }^{1}$ Одна находка в Кривая Лука VI, к. 12/п.1 (Дворниченко, Малиновская, Федоров-Давыдов, 1977, с. 73-74, рис. 102-2) (Рис. 8-Б), вторую установить не удалось. 


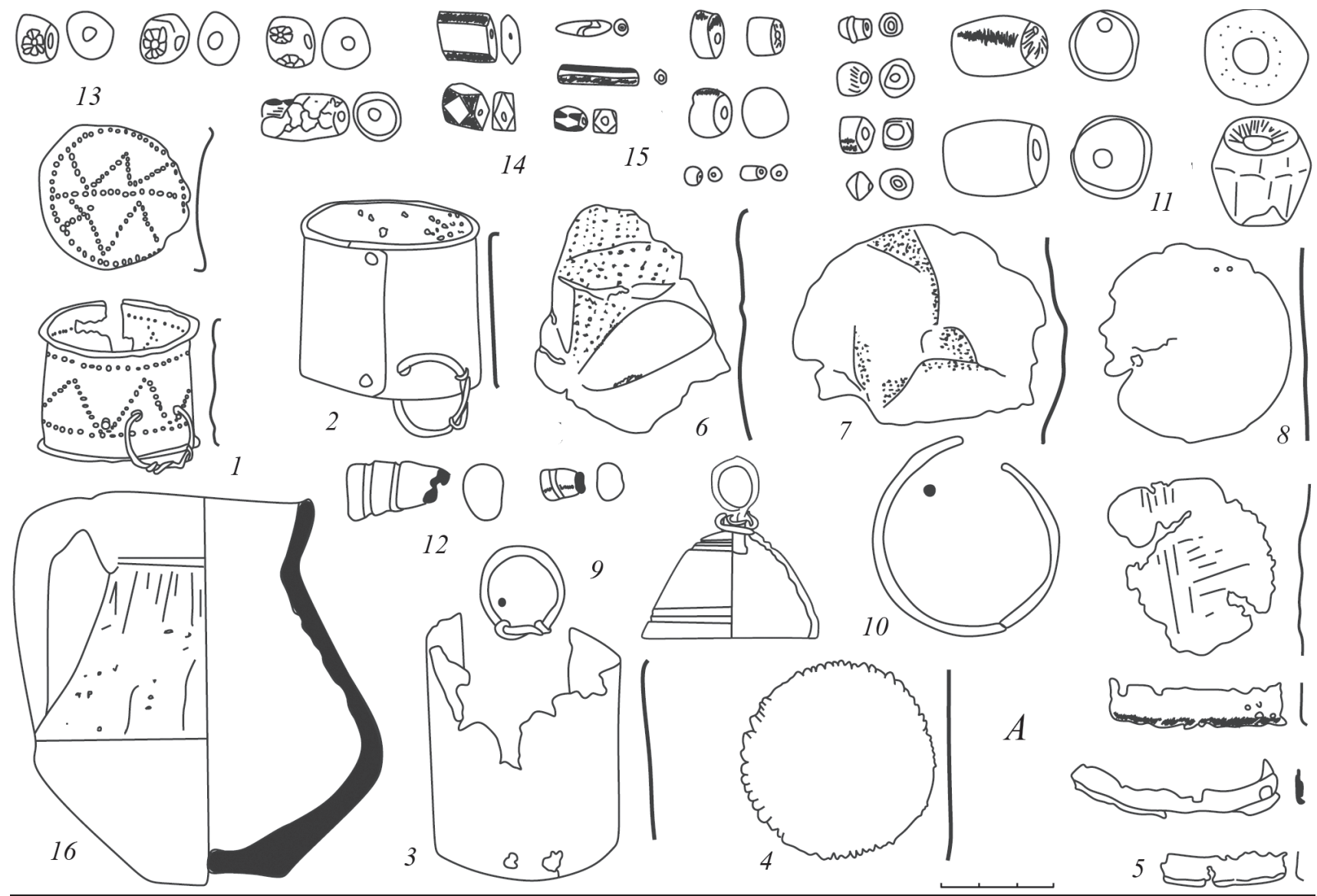

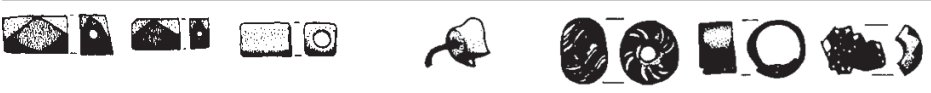

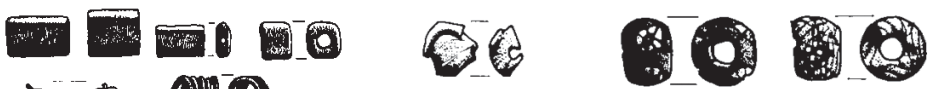

बे.

010

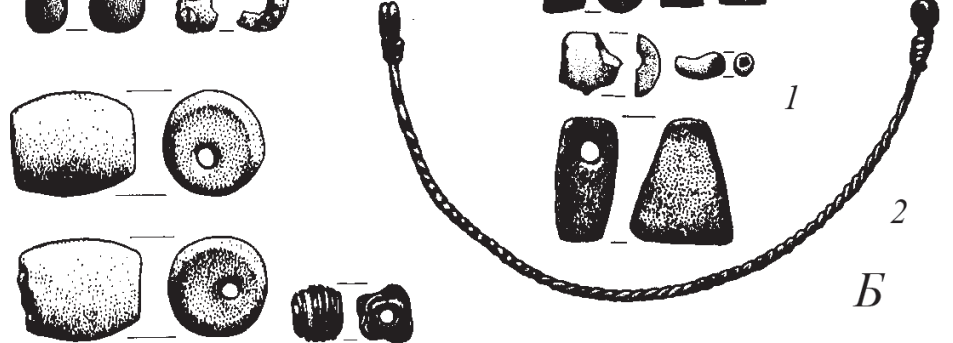

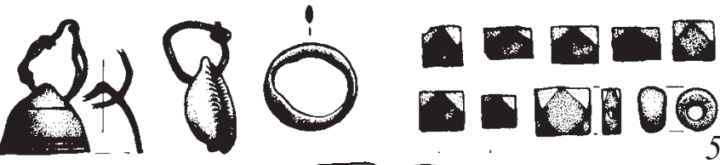
100000000000

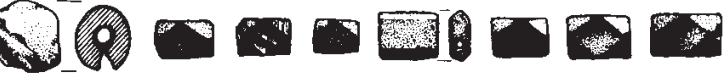
-60 -0 a 000000 000000000
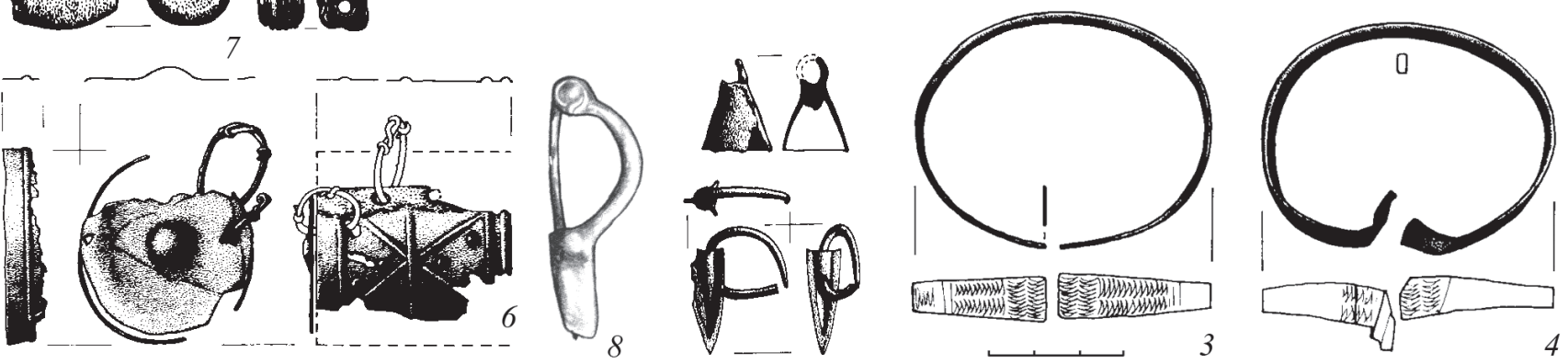

Рис. 1. А - Pančevo-Vojlovica, п. 24 [Grumeza, 2014, pl. 73], Б - Kiskundorozsma-Subasa, 26/78, п. 121 [Bozsik, 2003, kep. 4-9, 11-13] (сохранена нумерация оригиналов) 


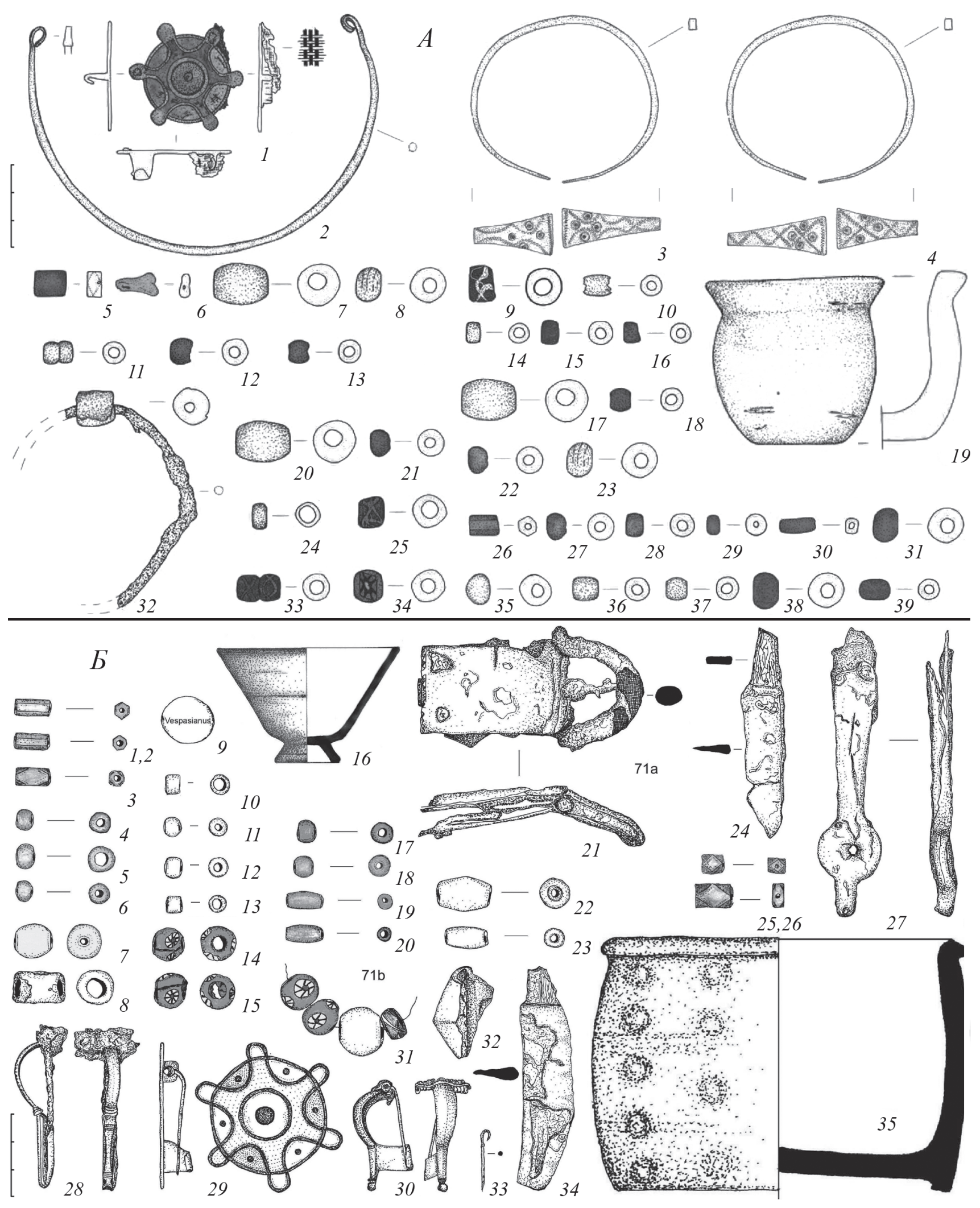

Рис. 2. А - Mako-Pap-hat 1, п. 14 [Gyöngyi, 2012, abra 13-15], Б - Abony-39, п. 71 [Gyöngyi, 2011, tabla 29-30] 

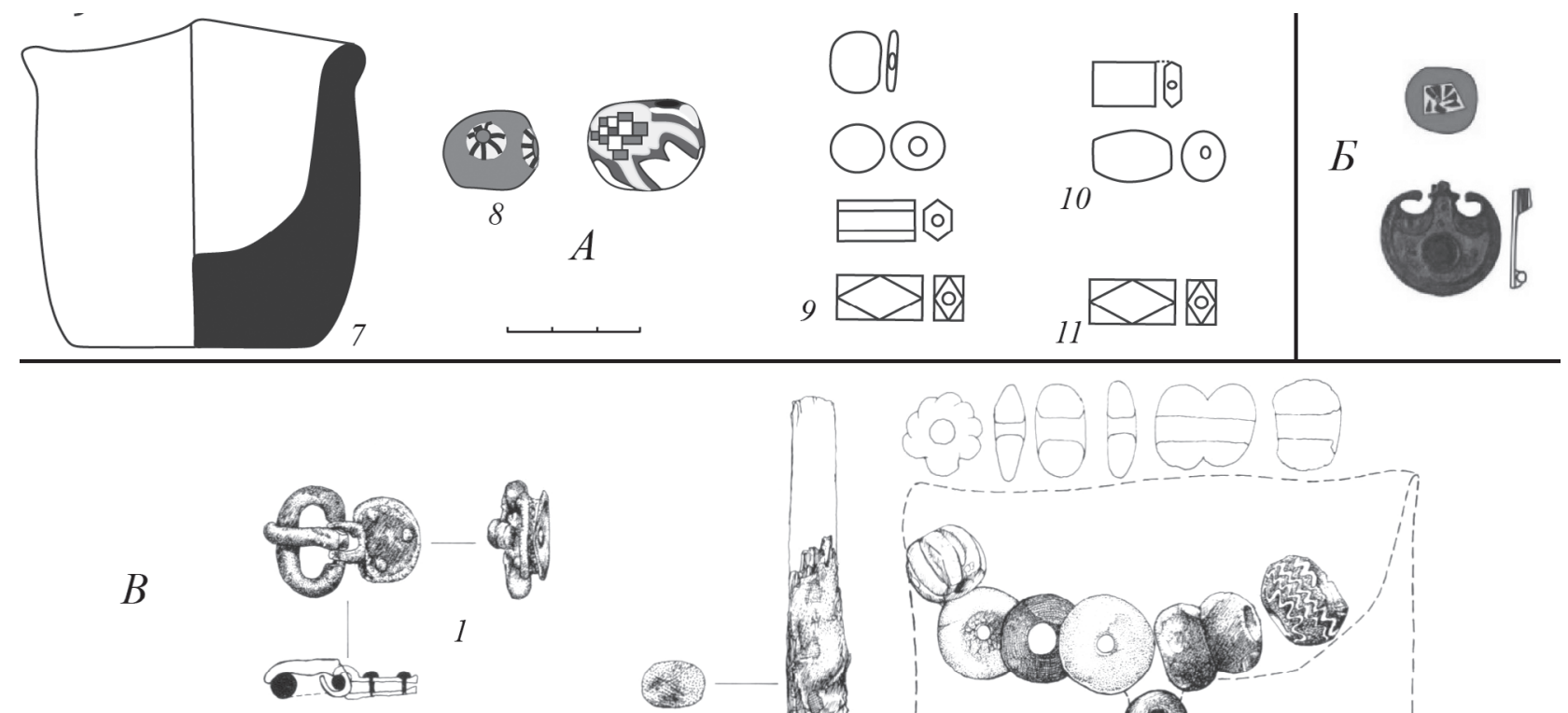

8

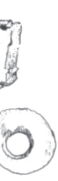

(o)
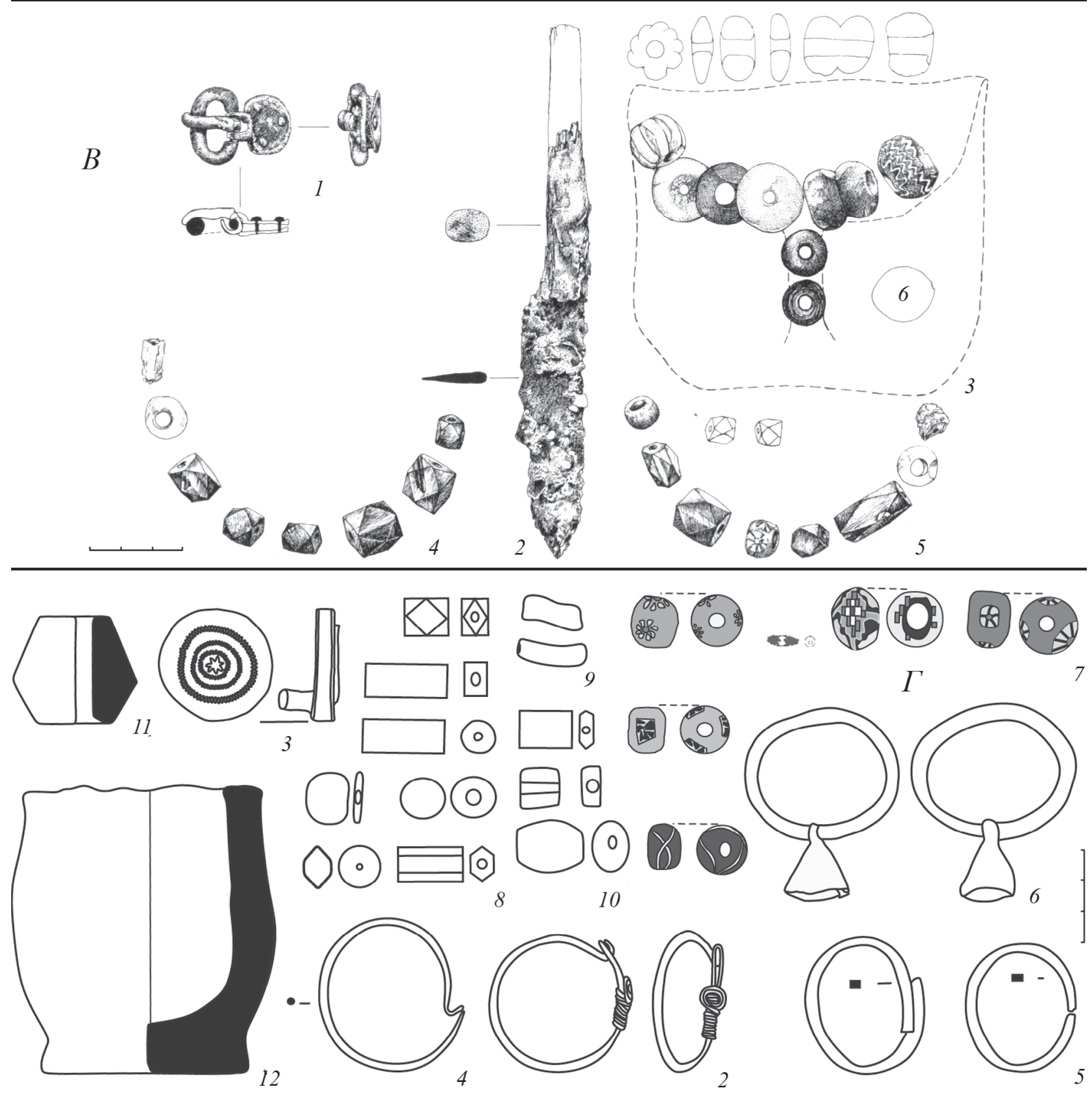

8

10
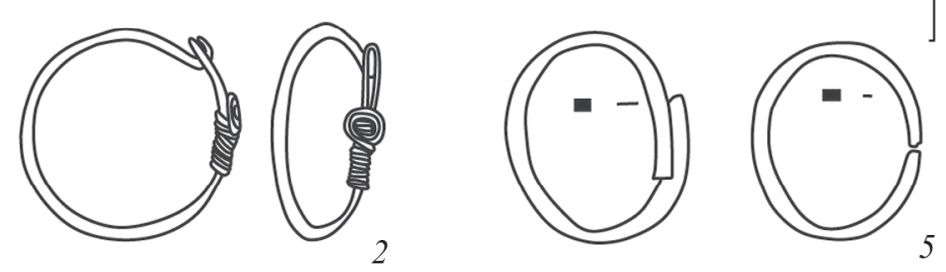

Рис. 3. A - Foeni-Cimitirul Ortodox, п. 15) [Grumeza, 2014, pl. 20-7-11],

Б - Foeni-Cimitirul Ortodox, п. 8) [Grumeza, 2018, pl. VII], В - Tiszadob-Sziget, п. 19 [Istvanovits, 1993, Abb. 10], Г - Foeni-Cimitirul Ortodox, п. 14)

[Grumeza, 2014, pl. 19-1-12] (для А, Г сохранена нумерация оригиналов) 

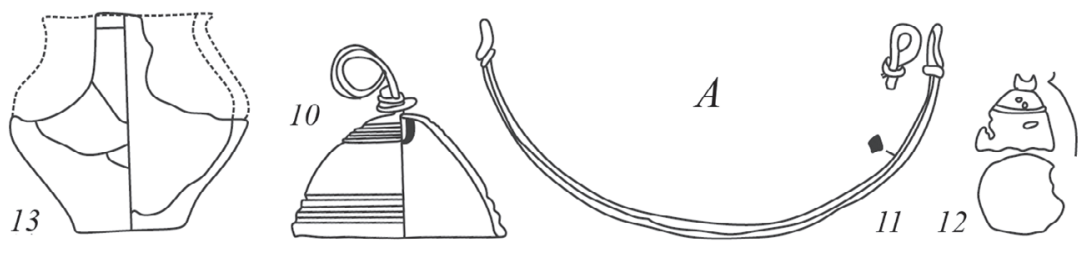

(1)(20) $=000$ (2) 900 (1) (-) 900 (a)
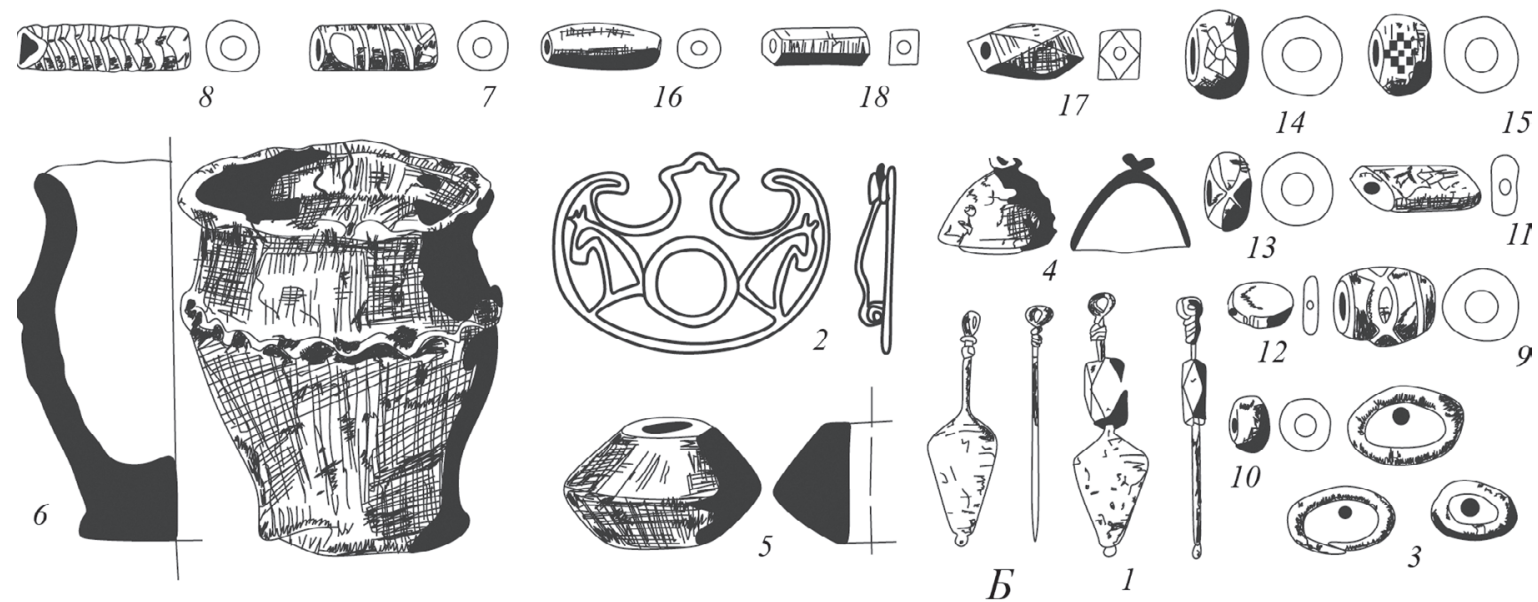

(0)
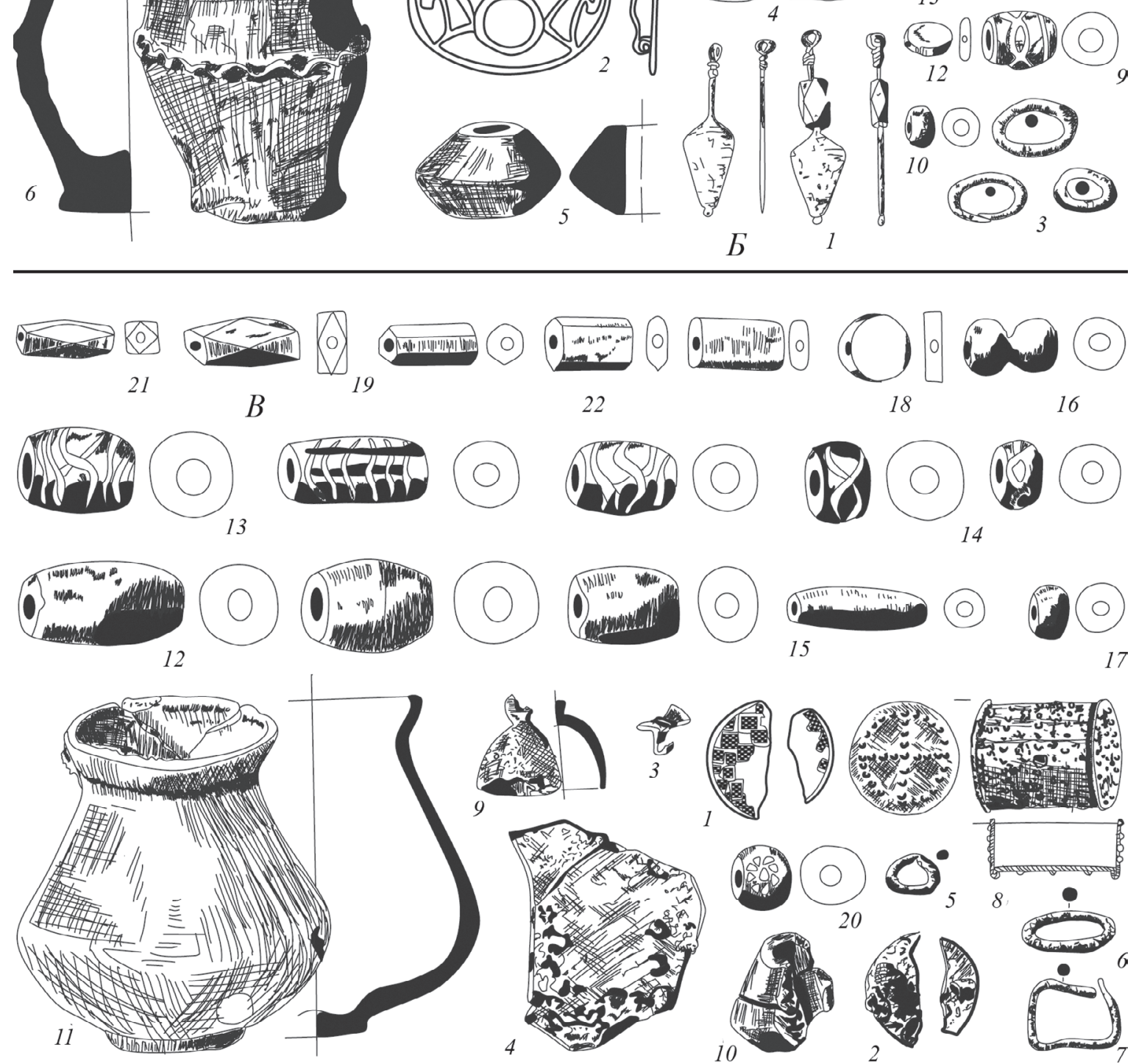

Рис. 4. A - Pančevo-Vojlovica, п. 49 [Grumeza, 2014, pl. 78-10-15], Б - Vršac-Dvorište Eparhije Banata, п. 14 [Grumeza, 2014, pl. 97-1-18],

B - Vršac-Dvorište Eparhije Banata, п. 6 [Grumeza, 2014, pl. 94] (сохранена нумерация оригиналов) 

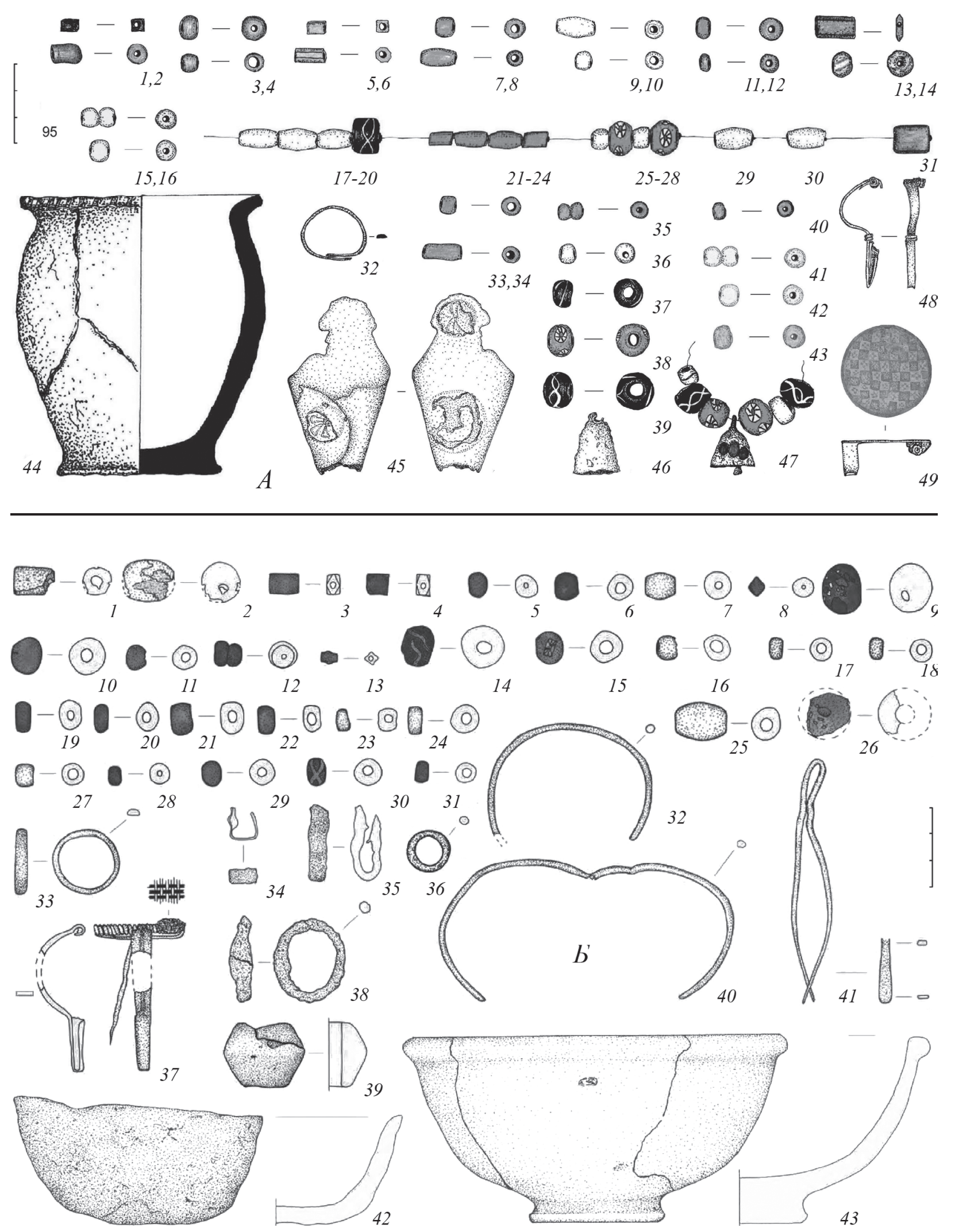

Рис. 5. А - Mako-Pap-hat 1, п. 2 [Gyöngyi, 2012, abra 3-5]; Б - Abony-39, п. 95 [Gyöngyi, 2011, tabla 33-34] 


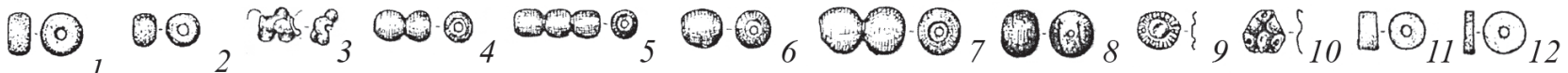

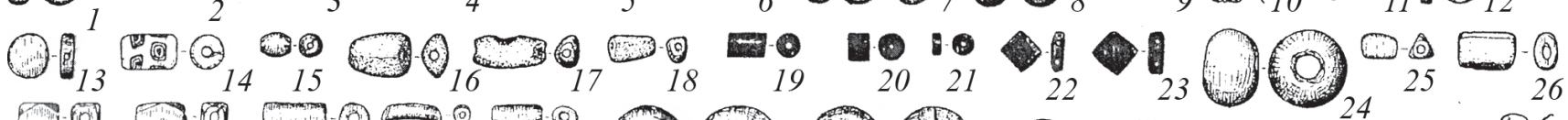
C.

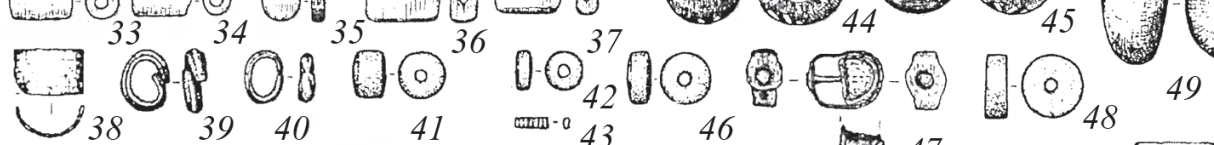
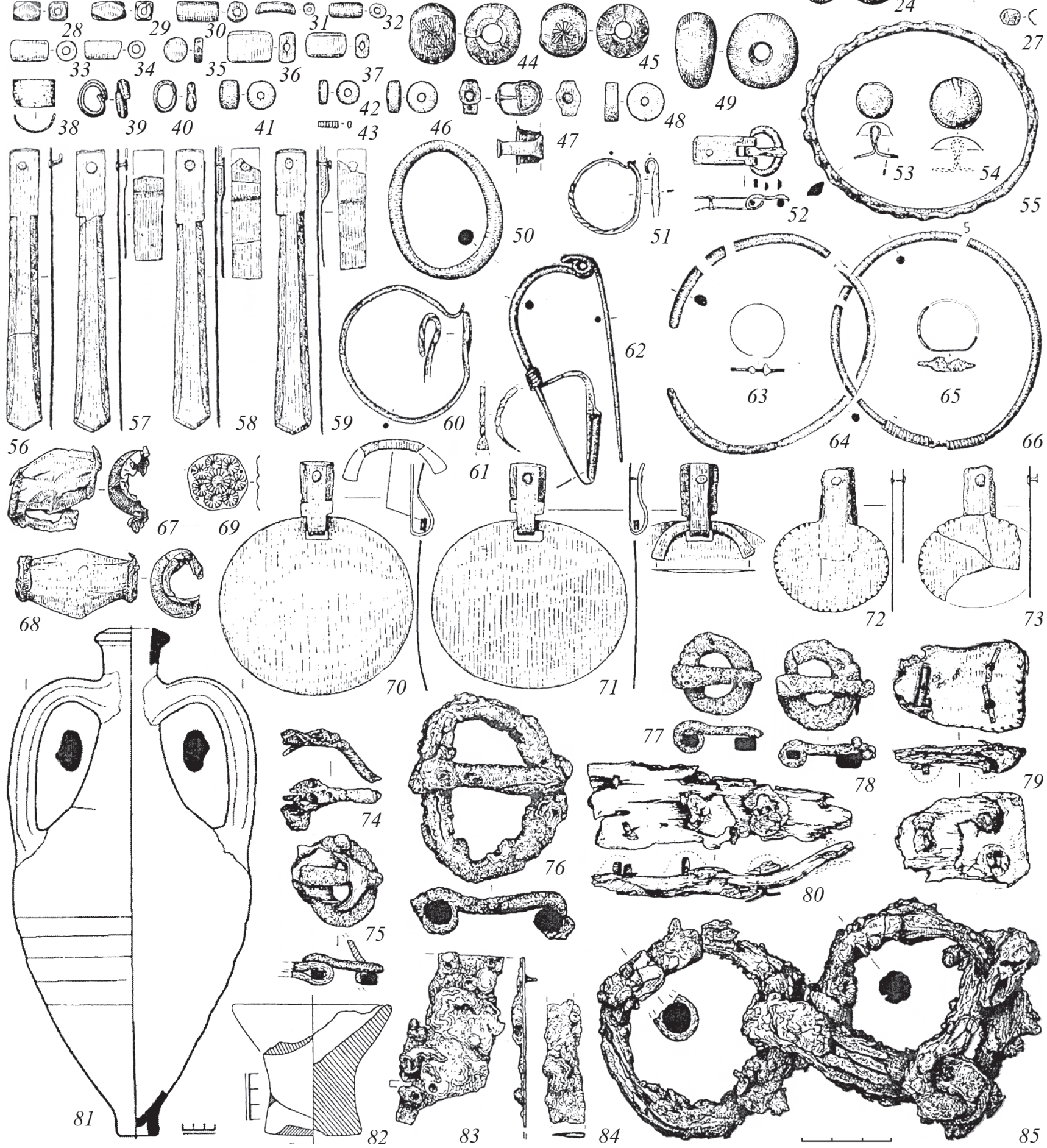


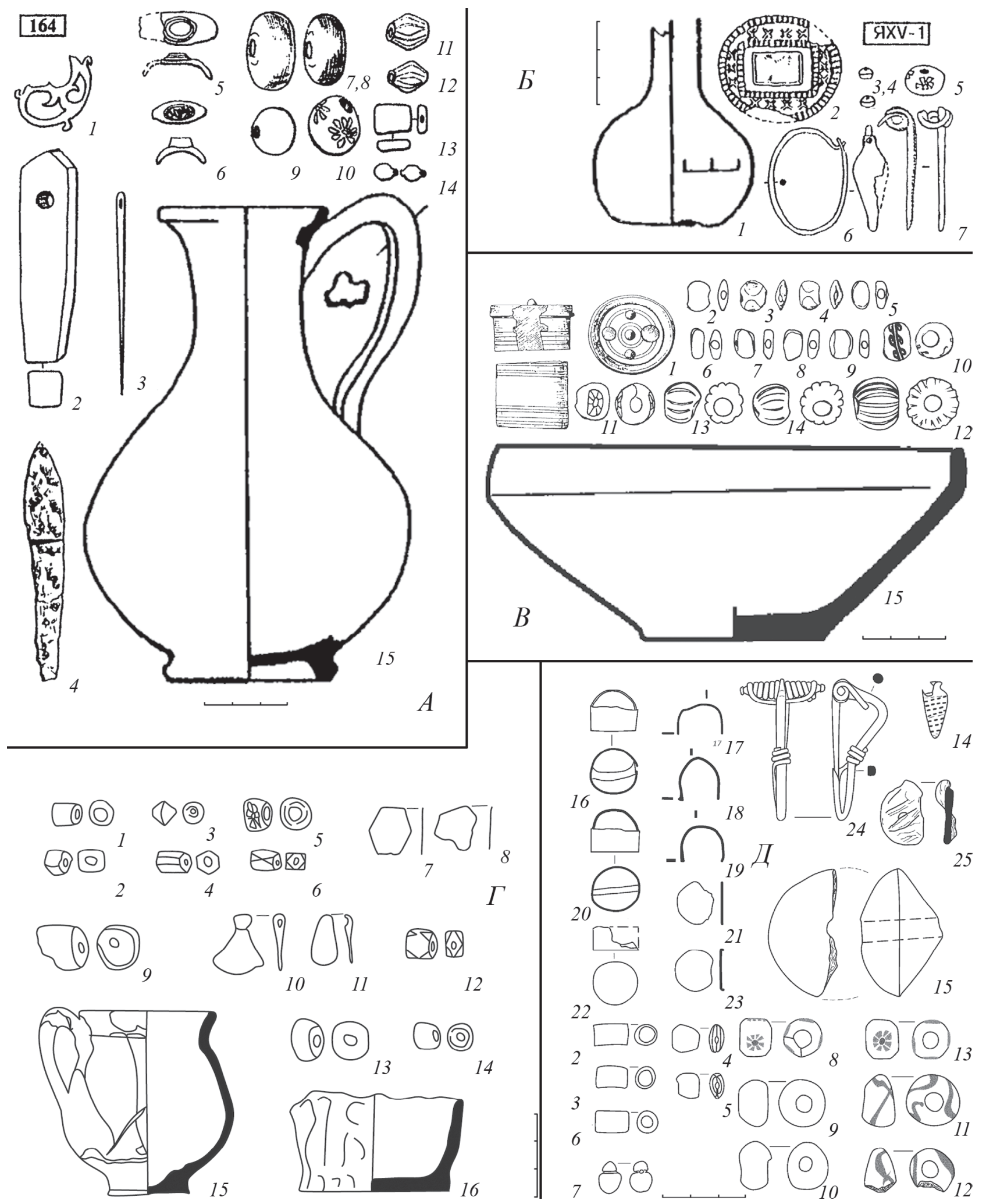

Рис. 7. А - Совхоз-10, п. 164 [Стржелецкий и др., 2003-2004, табл. 21-29-35], Б - Совхоз-10, п. 147=к.я.XV/у.1 [Стржелецкий и др., 2003-2004, табл. 59-18-24],

В - Ружичанка, п. 25 [Гопкало, 2008, рис. 1], Г - Pančevo-Vojlovica, п. 23 [Grumeza, 2014, pl. 72-9-13], Д - Чернелив 54 [Герета, 2013, рис. 32] (для В, Д сохранена нумерация оригиналов) 

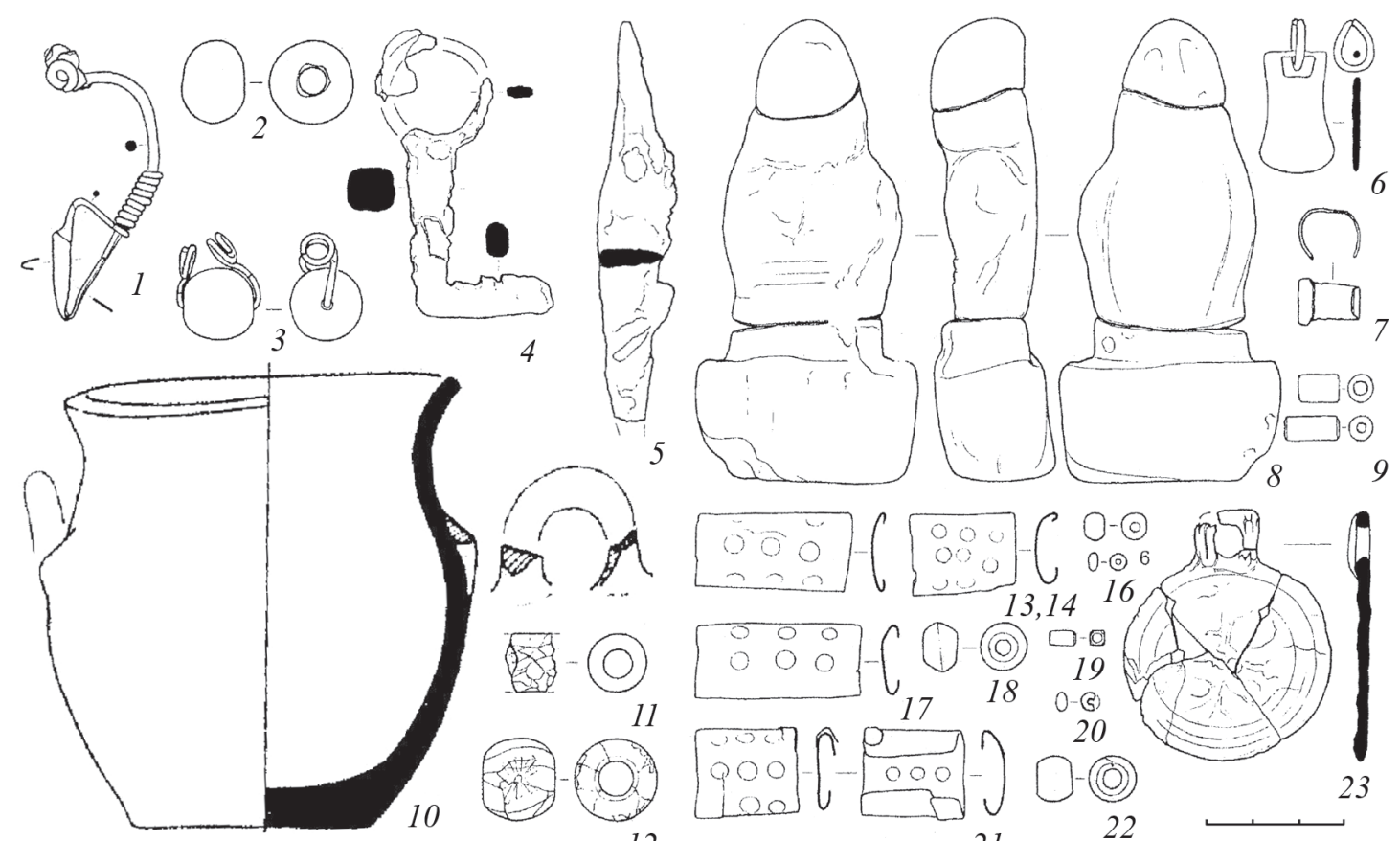

21

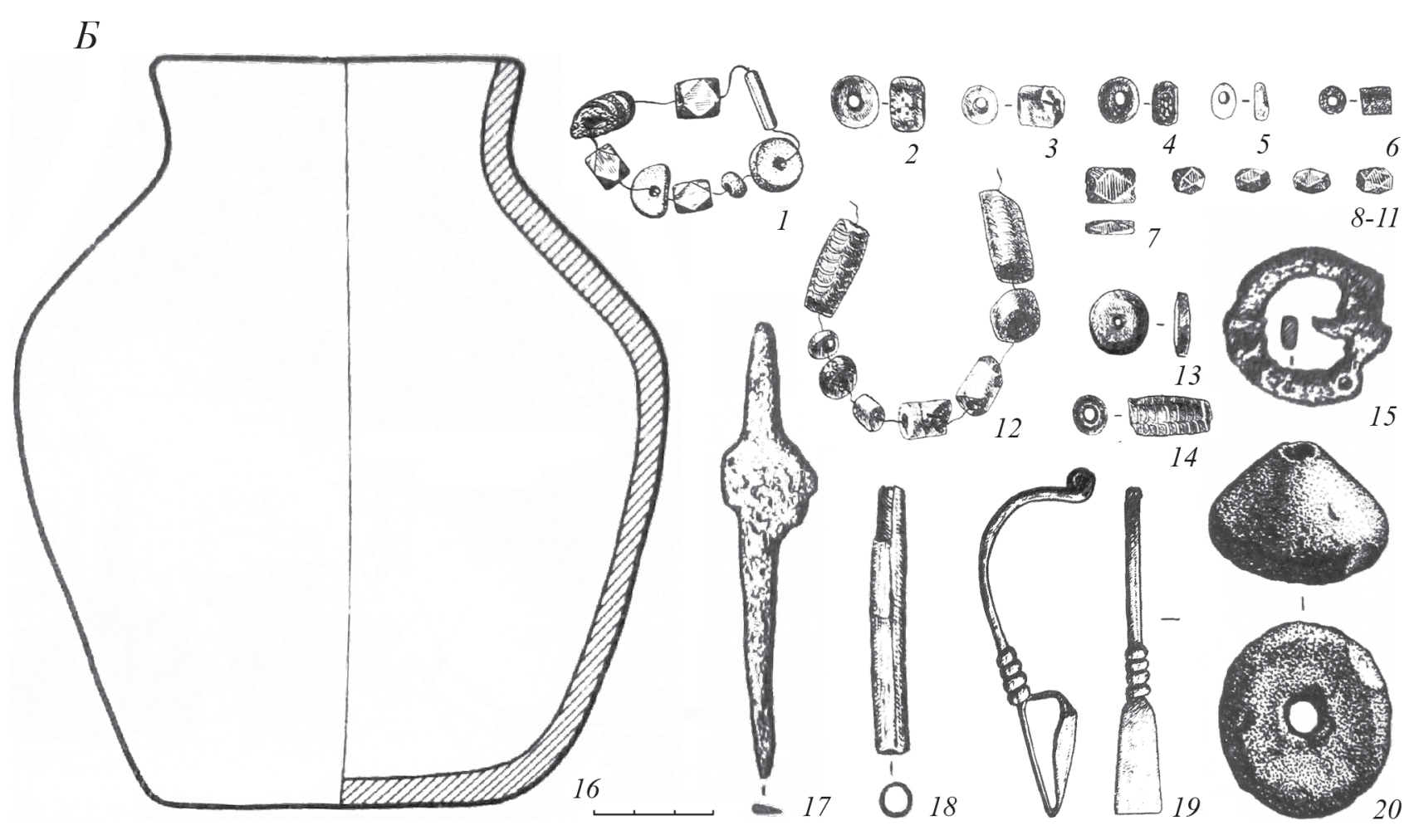

Рис. 8. А - Нейзац, п. 25 [Храпунов, 2006, рис. 36-37], Б - Кривая Лука VI, к. 12/п.1 [Дворниченко, Малиновская, Федоров-Давыдов, 1977, рис. 75-2, 82-6, 83-4, 86-5, 89-4, 92-4, 101, 102] 


\section{ИСТОЧНИКИ И ЛИТЕРАТУРА}

Алексеева, 1982 - Алексеева Е. М. Античные бусы Северного Причерноморья / САИ. ВыП. Г1-12. М.: Наука, 1982. 104 с.

Алексеева, 2007 - Алексеева Е. М., Сорокина Н. П. Коллекция стекла античной Горгипии (I-III вВ. н. э.). М.: Интербук-бизнес, 2007. 160 с.

Амброз, 1989 - Амброз А. К. Хронология древностей Северного Кавказа. М.: Наука, 1989. 134 с.

Безуглов, 2017 - Безуглов С. И. Позднесарматский курган у станицы Камышевской на Дону // Вестник Танаиса. Вып. 4. Недвиговка, 2017. С. 84-147.

Белевец, 2016 - Белевец В. Г. О находках топоровидных подвесок позднеримсокго времени на территории Беларуси // Черняхівська культура: до 85-річчя від дня народження І. С. Винокура. К., 2016. С. 59-67.

Бобровська, 2000 - Бобровська О. В. Намисто та підвіски у вбранні населення черняхівської культури / Автореф. дис. ... канд. іст. наук: 07.00.04. К: Інститут археології НАНУ, 2000. 20 с.

Внуков, 2006 - Внуков С. Ю. Причерноморские амфоры. І в. до н. э. - II в. н. э. Ч. II. Петрография, хронология, проблемы торговли. СПб., 2006. 320 с.

Высотская, Рыжсова, 1996 - Высотская Т. Н., Рыжова Л. А. Бусы могильника «Совхоз 10» («Севастопольский») // Древности. Харьков, 1996. С. 116-133.

Гей, Бажан, 1997 - Гей О. А., Бажан И. А. Хронология эпохи «готских походов» (на территории Восточной Европы и Кавказа). М., 1997. 144 с.

Герета, 2013 - Герета I. П. Чернелево-Руський могильник / OIUM. № 3. К.; Тернопіль: ТзОв «Терно-граф», 2013. 284 с.

Гопкало, 2008 - Гопкало О. В. Бусы и подвески черняховской культуры. К., 2008. 252 с., 2 вкл.

Гопкало, 2012 - Гопкало О. В. Черняховский могильник Ружичанка // Лесная и лесостепная зоны Восточной Европы в эпохи римских влияний и Великого переселения народов. Конф. 3 / Ред. А. М. Воронцов, И. О. Гавритухин. Тула: Государственный музей-заповедник «Куликово поле», 2012. C. $330-400$.

Гороховский, 1988 - Гороховский Е. Л. Хронология черняховских могильников Лесостепной Украины // Труды V Международного конгресса археологов-славистов. К., 1988. С. 34-46.

Дворниченко, Малиновская, Федоров-Давыдов, 1977 - Дворниченко В. В., Малиновская Н. В., Федоров-Давыдов Г. А. Раскопки курганов в урочище Кривая Лука в 1973 г. // Древности Астраханского края / ред. Г. А. Федоров-Давыдов. М.: Наука, 1977. С. 3-77, 85-194.

\section{REFERENCES}

Alekseeva, 1982 - Alekseeva E. M. Antichnye busy Severnogo Prichernomor'ya / SAI. Vyp. G1-12. M.: Nauka, 1982. 104 s. (in Russian)

Alekseeva, 2007 - Alekseeva E. M., Sorokina N. P. Kollekciya stekla antichnoj Gorgipii (I-III vv. n. e.). M.: Interbuk-biznes, 2007. 160 s. (in Russian)

Ambroz, 1989 - Ambroz A. K. Hronologiya drevnostej Severnogo Kavkaza. M.: Nauka, 1989. 134 s. (in Russian)

Bezuglov, 2017 - Bezuglov S. I. Pozdnesarmatskij kurgan u stanicy Kamyshevskoj na Donu // Vestnik Tanaisa. Vyp. 4. Nedvigovka, 2017. S. 84-147. (in Russian)

Belevec, 2016 - Belevec V. G. O nahodkah toporovidnyh podvesok pozdnerimsokgo vremeni na territorii Belarusi // Chernyahivs'ka kul'tura: do 85-richchya vid dnya narodzhennya I. S. Vinokura. K., 2016. S. 59-67. (in Russian)

Bobrovs 'ka, 2000 - Bobrovs'ka O. V. Namisto ta pidviski u vbranni naselennya chernyahivs'koï kul'turi / Avtoref. dis. ... kand. ist. nauk: 07.00.04. K: Institut arheologiï NANU, 2000. 20 s. (in Ukrainian)

Vnukov, 2006-Vnukov S. Yu. Prichernomorskie amfory. I v. do n. e. - II v. n. e. Ch. II. Petrografiya, hronologiya, problemy torgovli. SPb., 2006. 320 s. (in Russian)

Vysotskaya, Ryzhova, 1996 - Vysotskaya T. N., Ryzhova L. A. Busy mogil’nika «Sovhoz 10» («Sevastopol'skij») // Drevnosti. Har'kov, 1996. C. 116-133. (in Russian)

Gej, Bazhan, 1997 - Gej O. A., Bazhan I. A. Hronologiya epohi «gotskih pohodov» (na territorii Vostochnoj Evropy i Kavkaza). M., 1997. 144 s. (in Russian)

Iereta, 2013 - Iereta I. P. Chernelevo-Rus'kij mogil'nik / OIUM. № 3. K.; Ternopil': TzOv «Terno-graf», 2013. 284 s. (in Russian)

Gopkalo, 2008 - Gopkalo O. V. Busy i podveski chernyahovskoj kul'tury. K., 2008. 252 s., 2 vkl. (in Russian)

Gopkalo, 2012 - Gopkalo O. V. Chernyahovskij mogil'nik Ruzhichanka // Lesnaya i lesostepnaya zony Vostochnoj Evropy v epohi rimskih vliyanij i Velikogo pereseleniya narodov. Konf. 3 / Red. A. M. Voroncov, I. O. Gavrituhin. Tula: Gosudarstvennyj muzej-zapovednik «Kulikovo pole», 2012. S. 330-400. (in Russian)

Gorohovskij, 1988 - Gorohovskij E. L. Hronologiya chernyahovskih mogil'nikov Lesostepnoj Ukrainy // Trudy V Mezhdunarodnogo kongressa arheologov-slavistov. K., 1988. S. 34-46. (in Russian)

Dvornichenko, Malinovskaya, Fedorov-Davydov, 1977 - Dvornichenko V. V., Malinovskaya N. V., Fedorov-Davydov G. A. Raskopki kurganov v urochishche Krivaya Luka v 1973 g. // Drevnosti Astrahanskogo kraya / 
Диденко, 2014 - Диденко С. В. Хронология светлоглиняных узкогорлых амфор типов Шелов $\mathrm{D}$ и $\mathrm{F}$ (по материалам погребальных комплексов) // Черняхівська культура: до 120-річчя від дня народження В. П. Петрова / OIUM. № 4. К., 2014. С. 34-48.

Иванова, 2011 - Иванова О. С. Узкогорлые светлоглиняные амфоры из раскопок Мангупа // МАИЭТ. Вып. XVII. Симферополь, 2011. С. 266-327.

Иванова, 2013 - Иванова О. С. Амфоры позднеримского времени из раскопок Мангупа // Крым в сарматскую эпоху (II в. до н. э. - IV в. н. э.) / Ред. И. Н. Храпунов. Симферополь; Бахчисарай, 2013. С. 93-154.

Иитванович, Кульчар, 2017 - Иштванович Э., Кульчар В. Ведерковидные подвески в сарматском Барбарикуме карпатского бассейна (I-V вв. н. э.) // Європейська археологія I тисячоліття н.е.: Збірник наукових праць на честь Ліани Василівни Вакуленко. K., 2017. C. 51-62.

Кобылина, 1941 - Кобылина М. М. Раскопки некрополя Тиритаки 1934 // МИА. № 4 / Археологические памятники Боспора и Херсонеса / под ред. С. А. Жебелева и В. Ф. Гайдукевича. М.; Л.: изд-во AH CCCP, 1941. C. 75-84.

Комар, 2010 - Комар А. В. К дискуссии о хронологии раннесредневековых кочевнических памятников Среднего Поволжья // Культуры евразийских степей второй половины I тыс. н. э. (Вопросы межэтнических контактов и межкультурного взаимодействия). Самара, 2010. С. 169-207.

Костромичев, 2018 - Костромичев Д. А. Римское военное снаряжение из могильника Совхоз-10 // И. Н. Храпунов (науч. ред., сост.), Крым в сарматскую эпоху (II в. до н. э. - IV в. н. э.). III. Симферополь, 2018. C. 103-120.

Красноперов, 2019 - Красноперов А. А. Пряжка из Бродовского могильника (Прикамье) в контексте полихромных стилей // Лесная и лесостепная зоны Восточной Европы в эпохи римских влияний и Великого переселения народов. Конф. 4. Ч. 2 / ред. И. О. Гавритухин, А. М. Воронцов. Тула: ГМЗ «Куликово поле», 2019. С. 103-190.

Красноперов, в печати - Красноперов А. А. Бусы группы типов «Алексеева-480-482,490,496» (А-480482,490,496/Т-М-362) в Прикамье (в печати)

Кропотов, 2010 - Кропотов В. В. Фибулы сарматской эпохи. Киев, 2010.

Малашев, 2000 - Малашев В. Ю. Периодизация ременных гарнитур позднесарматского времени // Сарматы и их соседи на Дону / Отв. ред. Ю. К. Гугуев. Сер. Материалы и исследования по археологии Дона. Вып. 1. Ростов-на-Дону, 2000. С. 194-232. red. G. A. Fedorov-Davydov. M.: Nauka, 1977. S. 3-77, 85-194. (in Russian)

Didenko, 2014 - Didenko S. V. Hronologiya svetloglinyanyh uzkogorlyh amfor tipov Shelov D i F (po materialam pogrebal'nyh kompleksov) // CHernyahivs'ka kul'tura: do 120-richchya vid dnya narodzhennya V.P.Petrova/OIUM. №4. K., 2014. S. 34-48. (in Russian)

Ivanova, 2011 - Ivanova O. S. Uzkogorlye svetloglinyanye amfory iz raskopok Mangupa // MAIET. Vyp. XVII. Simferopol', 2011. S. 266-327. (in Russian)

Ivanova, 2013 - Ivanova O. S. Amfory pozdnerimskogo vremeni iz raskopok Mangupa // Krym v sarmatskuyu epohu (II v. do n. e. - IV v. n. e.) / Red. I. N. Hrapunov. Simferopol'; Bahchisaraj, 2013. S. 93-154. (in Russian)

Ishtvanovich, Kul'char, 2017 - Ishtvanovich E., Kul'char V. Vederkovidnye podveski v sarmatskom Barbarikume karpatskogo bassejna (I-V vv. n. e.) // Evropejs'ka arheologiya I tisyacholittya n.e.: Zbirnik naukovih prac' na chest' Liani Vasilivni Vakulenko. K., 2017. S. 51-62. (in Russian)

Kobylina, 1941 - Kobylina M. M. Raskopki nekropolya Tiritaki 1934 // MIA. № 4 / Arheologicheskie pamyatniki Bospora i Hersonesa / pod. red. S. A. ZHebeleva i V. F. Gajdukevicha. M.; L.: Izd-vo AN SSSR, 1941. S. 75-84. (in Russian)

Komar, 2010 - Komar A. V. K diskussii o hronologii rannesrednevekovyh kochevnicheskih pamyatnikov Srednego Povolzh'ya // Kul'tury evrazijskih stepej vtoroj poloviny I tys. n. e. (Voprosy mezhetnicheskih kontaktov i mezhkul'turnogo vzaimodejstviya). Samara, 2010. S. 169-207. (in Russian)

Kostromichev, 2018 - Kostromichev D. A. Rimskoe voennoe snaryazhenie iz mogil'nika Sovhoz-10// I. N. Hrapunov (nauch. red., sost.), Krym v sarmatskuyu epohu (II v. do n. e. - IV v. n. e.). III. Simferopol', 2018. S. 103-120. (in Russian)

Krasnoperov, 2019 - Krasnoperov A. A. Pryazhka iz Brodovskogo mogil'nika (Prikam'e) v kontekste polihromnyh stilej // Lesnaya i lesostepnaya zony Vostochnoj Evropy $\mathrm{v}$ epohi rimskih vliyanij i Velikogo pereseleniya narodov. Konf. 4. CH. 2 / red. I. O. Gavrituhin, A. M. Voroncov. Tula: GMZ «Kulikovo pole», 2019. S. 103-190. (in Russian)

Krasnoperov, v pechati - Krasnoperov A. A. Busy gruppy tipov «Alekseeva-480-482,490,496» (A-480482,490,496/T-M-362) v Prikam'e (v pechati). (in Russian)

Kropotov, 2010 - Kropotov V. V. Fibuly sarmatskoj epohi. Kiev, 2010. (in Russian)

Malashev, 2000 - Malashev V. YU. Periodizaciya remennyh garnitur pozdnesarmatskogo vremeni // Sarmaty i ih sosedi na Donu / Otv. red. YU. K. Guguev. Ser. 
Мульд, 2001 - Мульд С. А. Позднесарматское погребение в Центральном Крыму // МАИЭТ. Вып. VIII. Симферополь, 2001. С. 51-66.

Пуздровский, 2003 - Пуздровский А. Е. Склеп раннеримского времени из округи Неаполя скифского // Х Сб. Вып. ХІІ. Севастополь, 2003. С. 124-140.

Румянцева, 2008 - Румянцева О. С. Серия бус с полихромным декором с территории Поочья и Среднего Поволжья позднеримского времени // Лесная и лесостепная зоны Восточной Европы в эпохи римских влияний и Великого переселения народов. Вып. 1 / ред. И. О. Гавритухин, А. М. Воронцов. Тула, 2008. С. 90-110.

Румянщева, 2019 - Румянцева О. С. Находки полихромных бус на территории Среднего Поочья: хронология, распространение, социокультурный контекст // Лесная и лесостепная зоны Восточной Европы в эпохи римских влияний и Великого переселения народов. Конф. 4. Ч. 2 / ред. И. О. Гавритухин, А. М. Воронцов. Тула: ГМЗ «Куликово поле», 2019. С. 7-22.

Скрипкин, 1990 - Скрипкин А. С. Азиатская Сарматия. Проблемы хронологии и ее исторический аспект. Саратов: Изд-во Саратов. ун-та, 1990. 300 с.

Сорокина, 1977 - Сорокина Н. П. Античные стеклянные сосуды из раскопок некрополя боспорского города Кепы на Таманском п-ове // Античный мир и археология. Вып. 3. Саратов, 1977. С. 115-144.

Стоянова, 2004 - Стоянова А. А. Бусы и подвески из могильника Нейзац (по материалам раскопок 1996-2001 гг.) // БИ. Вып. V. Симферополь; Керчь, 2004. C. 263-320.

Стоянова, 2005 - Стоянова А. А. Металлические подвески в форме топориков из Крыма // Археологія. 2005. № 2. C. 47-54.

Стоянова, 2006 - Стоянова А. А. Намисто і підвіски населення Криму III ст. до н. е. - IV ст. н. е. / Автореф. дис. ... канд. іст. наук: 07.00.04. Київ, 2006. 20 с.

Стоянова, 2011 - Стоянова А. А. Аксессуары женского костюма II - первой половины III в. н. э. из могильника Нейзац // Исследования могильника Нейзац / Под ред. И. Н. Храпунова. Симферополь: Доля, 2011. С. 115-152.

Стоянова, 2016 - Стоянова А. А. Подвески из могильника Нейзац // Крым в сарматскую эпоху (II в. до н. э. - IV в. н. э.). II. 20 лет исследований могильника Нейзац / Отв. ред. И. Н. Храпунов. Симферополь: Наследие тысячелетий, 2016. С. 122-165.

Стржелеикийидр., 2003-2004-СтржелецкийС.Ф., Высотская Т. Н., Рыжова Л. А., Жесткова Г. И. Население округи Херсонеса в первой половине І тыс. н. э. (по материалам некрополя «Совхоз № 10»). Stratum plus. 2003-2004. № 4. C. 27-277.
Materialy i issledovaniya po arheologii Dona. Vyp. 1. Rostov-na-Donu, 2000. S. 194-232. (in Russian)

Mul'd, 2001 - Mul'd S. A. Pozdnesarmatskoe pogrebenie v Central'nom Krymu // MAIET. Vyp. VIII. Simferopol', 2001. S. 51-66. (in Russian)

Puzdrovskij, 2003 - Puzdrovskij A. E. Sklep rannerimskogo vremeni iz okrugi Neapolya skifskogo // H Sb. Vyp. XII. Sevastopol', 2003. S. 124-140. (in Russian)

Rumyanceva, 2008 - Rumyanceva O. S. Seriya bus s polihromnym dekorom s territorii Pooch'ya i Srednego Povolzh'ya pozdnerimskogo vremeni // Lesnaya i lesostepnaya zony Vostochnoj Evropy v epohi rimskih vliyanij i Velikogo pereseleniya narodov. Vyp. 1 / red. I. O. Gavrituhin, A. M. Voroncov. Tula, 2008. S. 90-110. (in Russian)

Rumyanceva, 2019 - Rumyanceva O. S. Nahodki polihromnyh bus na territorii Srednego Pooch'ya: hronologiya, rasprostranenie, sociokul'turnyj kontekst // Lesnaya i lesostepnaya zony Vostochnoj Evropy v epohi rimskih vliyanij i Velikogo pereseleniya narodov. Konf. 4. Ch. 2 / red. I. O. Gavrituhin, A. M. Voroncov. Tula: GMZ «Kulikovo pole», 2019. S. 7-22. (in Russian)

Skripkin, 1990 - Skripkin A. S. Aziatskaya Sarmatiya. Problemy hronologii i ee istoricheskij aspekt. Saratov: Izd-vo Saratov. un-ta, 1990. 300 s. (in Russian)

Sorokina, 1977 - Sorokina N. P. Antichnye steklyannye sosudy iz raskopok nekropolya bosporskogo goroda Kepy na Tamanskom p-ove // Antichnyj mir i arheologiya. Vyp. 3. Saratov, 1977. S. 115-144. (in Russian)

Stoyanova, 2004 - Stoyanova A. A. Busy i podveski iz mogil'nika Nejzac (po materialam raskopok 1996-2001 gg.) // BI. Vyp. V. Simferopol'; Kerch', 2004. S. 263-320. (in Russian)

Stoyanova, 2005 - Stoyanova A. A. Metallicheskie podveski $\mathrm{v}$ forme toporikov iz Kryma // Arheologiya. 2005. № 2. S. 47-54. (in Russian)

Stoyanova, 2006 - Stoyanova A. A. Namisto i pidviski naselennya Krimu III st. do n. e. - IV st. n. e. / Avtoref. dis. ... kand. ist. nauk: 07.00.04. Kiïv, 2006. 20 s. (in Ukrainian)

Stoyanova, 2011 - Stoyanova A. A. Aksessuary zhenskogo kostyuma II - pervoj poloviny III v. n. e. iz mogil'nika Nejzac // Issledovaniya mogil'nika Nejzac / Pod red. I. N. Hrapunova. Simferopol': Dolya, 2011. S. 115-152. (in Russian)

Stoyanova, 2016 - Stoyanova A. A. Podveski iz mogil'nika Nejzac // Krym v sarmatskuyu epohu (II v. do n. e. - IV v. n. e.). II. 20 let issledovanij mogil'nika Nejzac / Otv. red. I. N. Hrapunov. Simferopol': Nasledie tysyacheletij, 2016. S. 122-165. (in Russian) 
Труфанов, 2005-2009- Труфанов А. А. Хронология могильников Предгорного Крыма I в. до н. э. III в. н. э. // Stratum plus. 2005-2009. № 4. C. 117-328.

Хомякова, 2012 - Хомякова О. А. Хронология компонентов женского убора самбийско-натангийской культуры // Лесная и лесостепная зоны Восточной Европы в эпохи римских влияний и Великого переселения народов. Конф. 3 / Ред.: А. М. Воронцов, И. О. Гавритухин. М.: ИА РАН, 2012. С. 255-280.

Храпунов, 2006 - Храпунов И. Н. Погребения детей в могильнике Нейзац // МАИЭТ. Вып. ХІІ. Ч. 1. Симферополь, 2006. С. 161-250.

Храпунов, 2008 - Наконечники ремней из могильника Нейзац // МАИЭТ. Вып. XIV. Симферополь, 2008. C. 61-79.

Храпунов, 2011 - Храпунов И. Н. Некоторые итоги исследований могильника Нейзац // Исследования могильника Нейзац / Под ред. И. Н. Храпунова. Симферополь: Доля, 2011. С. 13-114.

Шелов, 1978 - Шелов Д. Б. Узкогорлые светлоглиняные амфоры первых веков нашей эры. Классификация и хронология // КСИА. Вып. 156 / Античность и варварский мир. М., 1978. С. 16-22.

Andrzejowski, 2018 - Andrzejowski J. Jartypory-type brooches - traces of a 'living culture' or just a research construct? // Kulturkonzepte und konzipierte Kulturen. Bonn: Dr. Rudolf Habelt GmbH, 2018. S. 99-128.

Benea, 2004 - Benea D. Die Romischen Perlenwerkstaetten aus Tibiscum / Atelierele romane de margele de la Tibiscum. Timisoara: Excelsior Art, 2004. 287 p.

Bozsik, 2003 - Bozsik K. Szarmata-sirok a Kiskundorozsma-Subasai 26/78. Szamu Lelohelyen // Uton. Utfelen / Szerkesztette Sz. Csaba. Szeged, 2003. P. 97-106.

Grumeza, 2014 - Grumeza L. Sarmatian cemeteries from Banat (late 1st - early 5th centuries AD). Cluj Napoca: Mega Publishing House, 2014. 414 p.

Grumeza, 2018 - Grumeza L. Fashion by rituals: Rosette glass beads found in Sarmatian and Sântana de Mureș-Chernyakhov cultures (1st c. BC - 4th c. AD) // Arheologia Moldovei. 2018. № 1. P. 193-218.

Grumeza, 2020 - Grumeza L., Bârcă V. Glass beads found in Sarmatian cemeteries from southwestern Romania // Археологія і давня історія України. 2020. № 3 (in press)

Gyöngyi, 2011 - Gyöngyi G. Szarmata temetkezések Abony es Cegléd környékén // Studia Comitatensia. 31. 2011. S. 125-253.

Gyöngyi, 2012 - Gyöngyi G. Szarmata temetörészletek Makó környekéről (Csongrád megye) - Sarmatian cemetery sections in the vicinity of Makó (Csongrad County) // Évkönyv és jelentés a Kulturális Örökségvédelmi Szakszogálat 2009. évi feltárásairól. 2009. Field
Strzheleckij i dr., 2003-2004 - Strzheleckij S. F., Vysotskaya T. N., Ryzhova L. A., Zhestkova G. I. Naselenie okrugi Hersonesa v pervoj polovine I tys. n. e. (po materialam nekropolya «Sovhoz № 10»). Stratum plus. 2003-2004. № 4. S. 27-277. (in Russian)

Trufanov, 2005-2009 - Trufanov A. A. Hronologiya mogil'nikov Predgornogo Kryma I v. do n. e. III v. n. e. // Stratum plus. 2005-2009. № 4. S. 117-328. (in Russian)

Homyakova, 2012 - Homyakova O. A. Hronologiya komponentov zhenskogo ubora sambijsko-natangijskoj kul'tury // Lesnaya i lesostepnaya zony Vostochnoj Evropy v epohi rimskih vliyanij i Velikogo pereseleniya narodov. Konf. 3 / Red.: A. M. Voroncov, I. O. Gavrituhin. M.: IA RAN, 2012. S. 255-280. (in Russian)

Hrapunov, 2006 - Hrapunov I. N. Pogrebeniya detej v mogil'nike Nejzac // MAIET. Vyp. XII. CH. 1. Simferopol', 2006. S. 161-250. (in Russian)

Hrapunov, 2008 - Nakonechniki remnej iz mogil'nika Nejzac // MAIET. Vyp. XIV. Simferopol', 2008. S. 61-79. (in Russian)

Hrapunov, 2011 - Hrapunov I. N. Nekotorye itogi issledovanij mogil'nika Nejzac // Issledovaniya mogil'nika Nejzac / Pod red. I. N. Hrapunova. Simferopol': Dolya, 2011. S. 13-114. (in Russian)

Shelov, 1978 - Shelov D. B. Uzkogorlye svetloglinyanye amfory pervyh vekov nashej ery. Klassifikaciya i hronologiya // KSIA. Vyp. 156 / Antichnost' i varvarskij mir. M., 1978. S. 16-22. (in Russian) 
Service for Cultural Heritage Yearbook and Review of Archaeological Investigations. Szerk.: Kvassay J. Budapest, 2012. S. 253-296.

Istvanovits, 1993 - Istvanovits E. Das Graberfeld aus dem 4.-5. Jahrhundert von Tiszadob-Sziget // ActaArchHung, 45, 1993. S. 91-146.

Köhegyi, 1989-1990 - Köhegyi M., Vörös G. 3-4. Századi temetö és 4-5. századi település Szeged-Algyön // A Móra Ferenc Múzeum évkönyve (1989/90). P. 63-116.

Köhegyi, 2011 -Köhegyi M., Vörös G. Madaras-halmok: Kr. u. 2-5. századi szarmata temető. Szeged: Szegedi Tudományegyetem Régészeti Tanszék, 2011. 455 p.

Madyda-Legutko, 2011 - Madyda-Legutko R. Studia nad zróznicowaniem metalowich części pasów w kulture przeworskiej. Okucia końca pasa. Kraków, 2011. 312 s.

Stawiarska, 1987 -Stawiarska T. Katalog paciorków szklanych z obszaru Polski północnej w okresie wpływów rzymskich. Wrocław: Ossolineum, 1987. $147 \mathrm{~s}$.

Tempelmann-Maczyńska, 1985 - Tempelmann-Mączyńska M. Perlen der römischen Kaiserzeit und frühen Phase der Völkerwanderungszeit im mitteleuropäischen Barbaricum. Mainz am Rhein, 1985. 430 p.

Vaday, 2003 - Vaday A. H. Cloisonne brooches in the Sarmatianbarbaricum // Acta Archaeologica Academiae Scientiarum Hungricae. LIV. 3-4. 2003. P. 276-315.

A. A. Krasnopeorov

\section{DATING OF COMPLEXES WITH BEADS OF T-M-362 TYPE ON THE ROMAN BORDERLANDS IN CONNECTION WITH FINDS IN THE KAMA REGION}

The solution of the questions of the Kama region archaeological chronology can be based on the dating of "imported" objects with a known chronological position: brooches, buckles, beads, etc. The article is part of a series dedicated to one group of beads - Rosette Glass Beads - T-M-362 / A-480-482,490,496. Beads of this group were found in 38 burials of 8 'Mazunino' archaeological culture, 10 burials of 4 'Azelino' archaeological culture burial grounds. For the correct transfer of the dates and understanding the chronological possibilities of the finds, in this case the finds of the beads of the T-M-362 group in the Kama region, it is necessary to consider the dating of the complexes in other regions of their existence. This publication focuses on complexes in the Roman borderlands: in the Sarmatian and Chernyakhov location. As the review has shown, "rosette" beads are characteristic of the Sarmatian groups on the Limes, but then the number of finds sharply decreases. According to accompanying finds, burials from the territory of modern Serbia, Hungary, Romania, date back to the $2^{\text {nd }}$ half of the II $-1^{\text {st }}$ half of the III centuries AD, with unit delays. This is in line with the dates suggested for the category of finds as a whole.

Keywords: Burial grounds, chronology, beads, 'Sarmatian' culture, 'Chernyakhov' culture, Kama region.

Красноперов Александр Анатольевич, научный сотрудник,

Удмуртский институт истории, языка, литературы УдмФИЦ УрО РАН

(Ижевск, Россия)

khaa@udm.ru

\author{
Krasnopeorov Alexander Anatolievich, \\ Research Associate, \\ Udmurt Institute of History, Language and Literature \\ UdmFRC UB RAS \\ (Izhevsk, Russia) \\ khaa@udm.ru
}

